\title{
Empirical Analysis of the Relationships between inward FDI and Business Cycles in Malaysia
}

\author{
Manal Suliman Omer \& Liu Yao (Corresponding author) \\ Faculty of Technology Management, University Malaysia Pahang \\ Kuantan, 26300, Malaysia \\ Tel.: 60-14-292-1640Ｅ-mail: xiaoyao6554@gmail.com
}

Received: February 28, 2011

Accepted: March 8, 2011

doi:10.5539/mas.v5n3p157

\begin{abstract}
Globalization has been spreading macro economic effects around the world as well as fueling firms' cross-national activities. Are there any links between these two influences? This paper chose Malaysia as subject and examined the causal relationships between inward foreign direct investment (FDI) and business cycles. A set of models based on Granger Causality test and VAR Impulse Responses were constructed. Time-series data covered from 1970 to 2008. And the findings clearly indicated that in the case of Malaysia, there is evidence of bi-directional causality and long-run relationships between firms' (foreign) activities (inward FDI) and business cycle developments in a long term.
\end{abstract}

Keywords: Business cycles, Inward FDI, Granger Causality test, VAR Impulse Responses

\section{Introduction}

During the process of globalization, the transmission of macro-economic developments across countries has been largely increased. But how does such transmission happen? Activities of multinational firms, such as FDI, are believed to be one possible answer (Christiano \& Fitzgerald, 1998; Bruce A. Blognigen, 2005), as it has been acknowledged to be most crucial in economic growth enhancing (Chowdhury \& Mavrotas, 2006; Hansen \& Rand, 2006) mainly through the capital, technology and know-how that it brings into the host country. By transferring knowledge (Karimi, et al. 2009), FDI is supposed to increase the existing stock of knowledge in the host countries through labor training, transfer of skills, and transfer of new managerial and organizational practice. FDI could also promote the utilization of more advanced technologies in domestic firms through capital accumulation in the domestic countries (Barba and Venables, 2004). Moreover, FDI is thought to open up export markets (Ghironi and Melitz, 2004) and to promote domestic investments through the technological spillovers (Claudia and Lipponer, 2005) and the resulting productivity increase.

In general, the voluminously motivated empirical researches on the relationship have studied from four main channels: determinants of growth, determinants of FDI, role of multinational firms in host countries and direction of causality between the two variables (Karimi et.al, 2009). And amongst them, there are mainly two separate thoughts of related research with their own limitations. The first branch of the literature focuses on the determinants and effects of the activities of multinational firms, by stressing long-term fundamentals such as the absolute and relative factor endowments of countries, the distance between markets and trade and investment costs, etc. But it typically ignores the impact of short- term business cycle fluctuations which serves as a trigger of entering into new markets. The second branch of the literature studies the importance of firm heterogeneity in its response to macroeconomic shocks, by employing, especially recently, the open macro-economic models. But those models have paid too much attention to the impact of firm heterogeneity. And in those models, fixed costs and firm heterogeneity in terms of productivity are regarded as reasons to explain why foreign activities of firms react to the cycle.

Given the complex relationship between FDI and business cycles across countries, this paper is mainly, therefore, aimed to combine these two strands of research by testing the bi-direction of causality between inward FDI activities and business cycles in the case of Malaysia. A macro-level annual data set covering several business cycle episodes (1970-2008) are used in this research following in two steps. Firstly, based on literature review, a testable hypothesis is formulated from visually investigation of the pictorial relationship between GDP and inward FDI. Secondly, empirical analysis is carried out to prove it with discussions and conclusions provided behind. 


\section{Literature Review}

Theoretically, neoclassical models of growth as well as endogenous growth models provide the basis for most of the empirical work on the FDI-growth relationship, although from different perspectives (Karimi et al, 2009). Solow-type standard neoclassical growth models suggest that FDI increases the capital stock and thus the growth in the host economy by financing capital formation (Brems and Hans, 1970). Admittedly, with diminishing returns to capital in neoclassical growth models, the impact of FDI on growth is identical to that of domestic investment and FDI has only a "short-run" growth effect as countries move towards a new steady state. However, in endogenous growth models, FDI is generally assumed to be more productive than domestic investment, since FDI encourages the incorporation of new technologies in the production function of the host economy (Borensztein et al., 1998). In this view, FDI-related technological spillovers offset the effects of diminishing returns to capital and keep the economy on a long-term growth path. Moreover, endogenous growth models imply that FDI can promote long-run growth by augmenting the existing stock of knowledge in the host economy through labor training and skill acquisition (Hanson and Slaughter, 2003), as well as through the introduction of alternative management practices and organizational arrangements (De Mello and Jr Luiz, 1999). Thus, through capital accumulation and knowledge spillovers (Niles, 2003), FDI plays an important role in host country's economic growth.

Thus from a theoretical perspective, it is reasonable to assume that FDI and business cycle is positively related. More empirical researches by using specific country data present more supportive evidences. Asheghian (2004) and Salehizadeh,(2005) confirm the existence of a positive and significant relationship between FDI and the economic growth in the United States. According to Kornecki \& Raghavan (2008), the Central and Eastern Europe (CEE) countries acknowledge FDI as an essential tool in the development and modernization of their economies. A number of studies find that FDI inflows have a strong and positive effect on economic growth in China (Tian, Lin, \& Lo, 2004). Fang \& Liu (2007) and Sharahili \& Liu (2008) have, after empirically analyzing Business Cycles and FDI through Evidence from Chinese panel data, pointed out that business cycles do have a strong impact on FDI projects. Then how about Malaysia? Chowdhury and Mavrotas (2006) examined the causal relationship between FDI and economic growth for three developing countries, namely Chile, Malaysia and Thailand and found that in Malaysia, there is a strong evidence of a bi-directional causality between the two variables. Duasa (2007) examined the causality between FDI and output growth in Malaysia, but the study found no strong evidence of causal relationship between FDI and economic growth. Thus they conclude that, in the case of Malaysia, FDI does not cause economic growth. Thus, this indicates that the relationship between FDI and economic growth is far from straightforward in the case of Malaysia.

Therefore, three types of causal relationship shall be under consideration: 1) there is a two-way causal link between FDI and business cycle or possibly no causality at all; 2) the growth of the host country attracts FDI inward, that is, growth-driven FDI; and 3) the FDI improves the growth rate of the host country, that is, FDI-led growth.

\section{Hypothesis}

Since related literature review hardly presents clearly unified FDI- Business cycle relation in Malaysia case, the research hypothesis in this study is going to be derived from the real economic data. From the visual viewpoint, Fig.1 shows the evolutions of the absolute values of inward FDI and GDP of Malaysia during the last three decades. According to it, there seems no clear similar moving trend between the two. Over this period, Malaysia had a consistent record of economic growth in GDP. But inward FDI experienced big ups and downs, maybe due to its open economy, on which externalities have had a major impact from time to time including the oil crises of the 1970s, the downturn in the electronics industry in the mid 1980s, and especially the Asian financial crisis in 1997. And the impact of this crisis was still being felt in the early twenty-first century.

But if investigating the relative values, i.e. the growth rate of inward FDI and GDP of Malaysia within the same period, the truth will be unveiled (seen in Fig.2). Fig.2 clearly shows that the two curves moved at a similar pace. For example, in 1975 and 2001, both reached trough. Then under the encouragement of policies, they both rebounded until the peak. Policy reforms, including the introduction of the Investment Incentives Act 1968, the establishment of free trade zones in the early 1970s, and the provision of export incentives alongside the acceleration of open policy in the 1980s, led to a surge of FDI in the late 1980s. To attract a larger inflow of FDI, the government introduced more liberal incentives including allowing a larger percentage of foreign equity ownership in enterprise under the Promotion of Investment Act (PIA), 1986. This effort resulted in a large inflow of FDI after 1987, with the inflow of FDI growing at an annual average rate of 38.7 percent between 1986 and 1996. 
Thus, after the visual investigation from the absolute, especially the relative values, it could roughly hypotheses that Malaysia's inward FDI and business cycle developments are relatively strongly and positively related in a long term. But how the interactions happen requires the following deeper inspection.

\section{Methodology and Data}

In order to solve aforementioned questions, Granger Causality test and VAR Impulse Responses are deployed as methodology tools under this research. As the two testing are very well known in the applied econometrics, the following paragraphs present brief description.

\subsection{Granger Causality Test}

The Granger causality test is a statistical hypothesis test for determining whether one time series is useful in forecasting another. Let $\mathrm{X}$ and $\mathrm{Y}$ be stationary time series with null hypothesis that $\mathrm{X}$ does not Granger-cause $\mathrm{Y}$. The time series $\mathrm{X}$ is said to Granger-cause $\mathrm{Y}$ if it can be shown, usually through a series of t-tests and F-tests on lagged values of $X$ (and with lagged values of $Y$ also included), that those $X$ values provide statistically significant information about future values of $\mathrm{Y}$.

Mathematically, to test the null hypothesis, firstly proper lagged values of $\mathrm{Y}$ are included in a univariate autoregression of $Y$ as:

$Y_{t}=a_{0}+a_{1} Y_{t-1}+a_{2} Y_{t-2}+\ldots \ldots+a_{m} Y_{t-m}+\operatorname{Re}$ sidual $_{t}$

Here $Y_{t-j}$ is retained in the regression if and only if it has a significant t-statistic; $\mathrm{m}$ is the greatest lag length for which the lagged dependent variable is significant.

Next, the autoregression is augmented by including lagged values of $\mathrm{X}$ as:

$Y_{t}=a_{0}+a_{1} Y_{t-1}+a_{2} Y_{t-2}+\ldots \ldots+a_{m} Y_{t-m}+b_{p} X_{t-p}+\ldots \ldots+b_{q} X_{t-q}+\operatorname{Re}$ sidual $_{t}$

One retains in this regression all lagged values of $X$ that are individually significant according to their t-statistics, provided that collectively they add explanatory power to the regression according to an F-test (whose null hypothesis is no explanatory power jointly added by the x's). In the notation of the above augmented regression, $\mathrm{p}$ is the shortest, and $\mathrm{q}$ is the longest, lag length for which the lagged value of $\mathrm{X}$ is significant. The null hypothesis that $\mathrm{X}$ does not Granger-cause $\mathrm{Y}$ is accepted if and only if no lagged values of $\mathrm{X}$ are retained in the regression.

\subsection{VAR Impulse Response}

Impulse response analysis is used widely in the empirical literature to uncover the dynamic relationship between macroeconomic variables within vector-autoregressive (VAR) models. It measures the time profile of the effect of a shock, or impulse, on the (expected) future values of a variable. By imposing specific restrictions on the parameters of the VAR model the shocks can be attributed an economic meaning (Watson, 1994).

The standard approach to identifying impulse responses imposes restrictions on a VAR model estimated in the $(\log )$ levels of the variables. It is known that if a nonstationary VAR model in levels is estimated, impulse responses are inconsistent at long horizons. More specifically, the impulse responses are inconsistent at long horizons as the horizon increases with the sample size; this is because the nonstationarity means the true impulse responses do not tend to zero as the horizon increases (Phillips, 1998).

The VAR impulse response functions are used in this study to produce the time path of the dependent variables in the VAR, to shocks from all the explanatory variables. If the system of equations is stable, any shock should decline to zero; or an unstable system would produce an explosive time path.

Data: The GDP and the foreign direct investment inflows for Malaysia were taken from the World Bank's World Development Indicators 2006 CD ROM, and online WDI from World Bank website. Annual time series data covering the period 1970-2008 for which data was available was used.

\section{Models, Results and Discussion}

In this section, Granger Causality test model is firstly constructed in order to disclose the way how inward FDI and business cycles influence each other. As the time series of absolute economic data normally contains high-level instability which could seriously distort the empirical results, this paper, following the normal way of stabilizing treatment, loginize the absolute value of GDP and inward FDI, noted as $\operatorname{lnYt}$ (LNGDP) and $\operatorname{lnFt}$ (LNFDI) respectively. The models are as follows:

$$
\begin{aligned}
& \text { M I: } \ln Y_{\mathrm{t}}=\mathrm{a}_{0}+\mathrm{a}_{11} \ln Y_{\mathrm{t}-1}+\mathrm{a}_{20} \ln F_{\mathrm{t}}+\mathrm{a}_{21} \ln F_{\mathrm{t}-1}+\mu_{1 \mathrm{t}} \\
& \text { M II: } \ln F_{\mathrm{t}}=\mathrm{b}_{0}+\mathrm{b}_{11} \ln F_{\mathrm{t}-1}+\mathrm{b}_{20} \ln Y_{\mathrm{t}}+\mathrm{b}_{21} \ln Y_{\mathrm{t}-1}+\mu_{2 \mathrm{t}}
\end{aligned}
$$


The NULL hypothesis of M I is H0: $\mathrm{a} 11=\mathrm{a} 20=\mathrm{a} 21=0$, that is, the growth of inward FDI doesn't contribute to the increase of GDP; meanwhile, the NULL hypothesis of M II is H0: b11 $=b 20=b 21=0$, which means the growth of GDP is not the reason of the increase of Inward FDI.

By operating the acquired data and statistics in EViews3.1, the OLS estimation results of the above models are as seen in Table 1. According to the results, F-value of M I comes to 4465.433. Given $\alpha=0.05$, as $\mathrm{F}$ value $>$ F0.05(3,34), we can say under the significant level of 0.05 , the testing result of Model I is robust, that is, the hypothesis $\mathrm{HO}$ should be rejected with the significance of $95 \%$. Thus, inward FDI could be regarded as the Granger Causality towards GDP. Meanwhile, as F-value of M II also exceeds F0.05 (3,34), GDP in turn contributes to be the Granger Causality towards FDI. Therefore, it could be initially concluded that the growth of GDP and the growth of inward FDI have some Granger Causality relations between each other.

To further study the results from the T-values of each coefficient, for M1 the current-period inward FDI, compared with former-period GDP, creates softer influence on the current-period of GDP. For M II, the former-period inward FDI, compared with the current GDP, has stronger impact on the current-period real inward FDI.

After researching "who impacts who more" in the section above, the test of VAR Impulse Responses is applied in the next step to study their responding sensitivities towards changes in a relatively longer term. Here, we use the growth rate values of GDP and inward FDI by differentiating the loginized values of GDP and inward FDI, noted as $\Delta \ln Y t$ (DLNGDP) and $\Delta \operatorname{lnFt}$ (DLNFDI) respectively.

Since the time series of DLNGDP and DLNFDI has already been supposed to be stable, we, following the theoretical principle of VAR Impulse Responses, construct a corresponding VAR model, with the maximum lagged period is 2(AIC and SC) and the operating results from Eviews 3.1 are as shown in Fig.3.

Fig.3 shows that: 1) the growth rate of Malaysia GDP responds significantly and rapidly to the variance of inward FDI, for it starts responding from the first period until the forth one and after the forth period its response comes to be stable. But when the growth rate of Malaysia GDP responses to its own variance, it takes five periods to come to be stable. 2) the inward FDI in China responds more significantly and continuously to its own variance than to the variance of GDP, as its responding to its own variance starts from the first period while to the variance of GDP starts from the second one, which means inward FDI is more sensitive towards its own movements. Then, two points could be picked out: a) the fluctuation of Malaysian inward FDI is effected firstly by its own movements, and then by Malaysian economy, i.e. the current-period inward FDI fluctuation would effect the- following-two-year economic movement; b) the inward FDI creates relatively faster effects on economy, which meets the reality according to the highly open characteristics of Malaysia economy.

\section{Conclusion}

So far, theoretical and empirical literature on multinational firms has focused on the reasons why they become multinational or why they extend their business into a particular country, and focused the effects of multinational activities towards the host and home countries (Claudia and Lipponer, 2005). However, this paper has added another dimension to the discussion from analyzing the relationships between business cycles and multinational activities, especially inward FDI by using Malaysian data and statistics, which are annual and cover a time period of 39 years (1970-2008). The empirical findings have clearly proved the testable hypothesis that firms' foreign activities (inward FDI) and the host country's business cycle developments could be Granger Causally related in a long term. Also from the VAR Impulse Responses test, it is clear that under the case of Malaysia, inward FDI is more sensitive to its own performance than to the economy but can effect the economy relatively faster.

This paper has taken only an initial look at the links between business cycles and inward FDI and there do exist some limitations. For example, the exchange rate between Malaysia Ringgit and US Dollars is fixed at $1 \mathrm{RM}=0.35$ USD in this research, but in reality, it always changes especially in current times. Thus, the statistics obtained from the models can only be for reference. Additionally, only two statistical tools with simple models are applied to explain the highly complex macro-economic phenomenon, which is obviously far from enough. Thus, for further work, to develop more reasonable regression models and to discover the original motivation of FDI inflow into host country would be one research direction to go.

\section{References}

Asheghian, P. (2004). Determinants of economic growth in the United States. The role of foreign direct investment. The international trade journal.18(1), 63-83.

Barba Navaretti, G. \& Venables, A. J. (2004). Multinational Firms in the World Economy. Princeton: Princeton 
University Press.

Borensztein, E. De Gregorio, J. \& Lee, J. W. (1998). How does foreign direct investment affect economic growth? Journal of International Economics. 45, 115-135.

Brems \& Hans. (1970). A Growth Model of International Direct Investment. The American Economic Review (AER). 60(3), 320 - 331.

Bruce A. Blognigen. (2005). A Review of the Empirical Literature on FDI Determinants. Atlantic Economic Journal, doi: 10.1007/s 11293-005-2868-9.

Chowdhury, A. \& Mavrotas, G. (2006). FDI and growth: What causes what? The World Economy. 29(1), 9.

Christiano, L. J. \& Fitzgerald, T. J. (1998). The Business Cycle: It’s Still a Puzzle. Economic Perspectives. 22 (4), 56-83.

Claudia M. Buch \& Alexander Lipponer. (2005). Business Cycles and FDI: Evidence from German Sectoral Data. Kiel Institute for World Economics. doi: 10.1007/s10290-005-0053-5

De Mello, Jr Luiz R. (1999). Foreign Direct Investment-led growth: evidence from time series and panel data. Oxford Economic Papers. 51, 133-154.

Duasa,J. (2007). Malaysian Foreign Direct Investment and Growth: Does Stability Matter? The journal of Economic Cooperation. 28(2), 83-98.

Ghironi, F., \& Melitz, M. J. (2004). International Trade and Macroeconomic Dynamics with 7. Heterogeneous Firms. NBER Working Paper 10540. National Bureau of Economic Research, Cambridge, Mass.

Hansen H., \& Rand, J. (2006). On the casual links between FDI and growth in developing countries. The World Economy. 29 (1), 21.

Hanson, G. H., \& Slaughter, M. J. (2003). The Role of Multinational Corporations in International Business Cycle Transmission: Skew Lines or Arbitrage Opportunities? University of San Diego, Tuck School of Business at Dartmouth and NBER http://www.uni-iel.de/ifw/konfer/kwc/slaughter.pdf.

Karimi, Mohammad Sharif \& Yusop, Zulkornain. (2009). FDI and Economic Growth in Malaysia. Available online at: http://mpra.ub.uni-muenchen.de/14999/

Kornecki,L \& Raghavan, S. (2008). FDI and Economic Growth: an Empirical Analysis of Central and Eastern European Countries. European Journal of Management. 8(4).

Niles Russ, K. (2003). The Endogeneity of the Exchange Rate as a Determinant of FDI: A Model of Money, Entry, and Multinational Firms. Mimeo. Johns Hopkins University.

Phillips, P.C.B. (1998). Impulse response and forecast error variance asymptotics in nonstationary VARs. Journal of Econometrics. 83, 21-56.

Qiyun Fang, Yao Liu. (2007). Empirical Analysis: Business Cycles and Inward FDI in China. American Journal of Applied Sciences. 4 (8), 800-804.

Salehizadeh, M. (2005). Foreign Direct Investment Inflows and the US Economy: An Empirical Analysis. Economic Issues. 10(2), 29-50. Retrieved from ABI/INFORM Global database.

Tian, X., Lin, S., \& Lo, V. I. (2004). Foreign Direct Investment and economic performance in transition economies: Evidence from China. Post-Communist Economies.16(4), 499-510.

Watson, M.W. (1994). Vector autoregressions and cointegration. In Handbook of Econometrics, Volume IV (eds. Engle, R.F. and McFadden, D.L.), Elsevier Science B.V.

Yahya Sharahili \& Yao Liu. (2008). Empirical Analysis II: Business Cycles and Inward FDI in China. American Journal of Applied Sciences. 5(10), 1409-1414. 
Table 1. Granger Causality test of Inward FDI and GDP

\begin{tabular}{|c|c|c|c|c|c|}
\hline \multicolumn{5}{|c|}{ M I } & \multicolumn{3}{c|}{ M II } \\
\hline Variables & coefficient & T-value & Variables & coefficient & T-value \\
\hline $\mathrm{a}_{0}$ & 0.289256 & 2.881066 & $\mathrm{~b}_{0}$ & -1.497366 & -1.815703 \\
\hline $\ln Y_{\mathrm{t}-1}$ & 0.963856 & 50.61202 & $\ln F_{\mathrm{t}-1}$ & 0.603070 & 4.880792 \\
\hline $\ln F_{\mathrm{t}}$ & 0.064522 & 3.345460 & $\ln Y_{\mathrm{t}}$ & 3.838321 & 3.345460 \\
\hline $\ln F_{\mathrm{t}-1}$ & -0.038902 & -1.965002 & $\ln Y_{\mathrm{t}-1}$ & -3.445100 & -3.023921 \\
\hline $\mathrm{R}^{2}$ & 0.997468 & & $\mathrm{R}^{2}$ & 0.873869 & \\
\hline $\mathrm{ADR}^{2}$ & 0.997245 & & $\mathrm{ADR}^{2}$ & 0.862740 & \\
\hline $\mathrm{DW}-$ value & 1.987701 & & DW-value & 2.259089 & \\
\hline F-value & 4465.433 & & F-value & 78.52017 & \\
\hline Sample range & $1970-2007$ & & Sample range & $1970-2007$ & \\
\hline
\end{tabular}

By operating the acquired data and statistics in EViews3.1, the OLS estimation results of the above models are as seen in Table 1. According to the results, F-value of M I comes to 4465.433. Given $\alpha=0.05$, as $\mathrm{F}$ value $>$ F0.05 $(3,34)$, we can say under the significant level of 0.05 , the testing result of Model $\mathrm{I}$ is robust, that is, the hypothesis H0 should be rejected with the significance of 95\%. Thus, inward FDI could be regarded as the Granger Causality towards GDP. Meanwhile, as F-value of M II also exceeds F0.05 (3,34), GDP in turn contributes to be the Granger Causality towards FDI. Therefore, it could be initially concluded that the growth of GDP and the growth of inward FDI have some Granger Causality relations between each other.

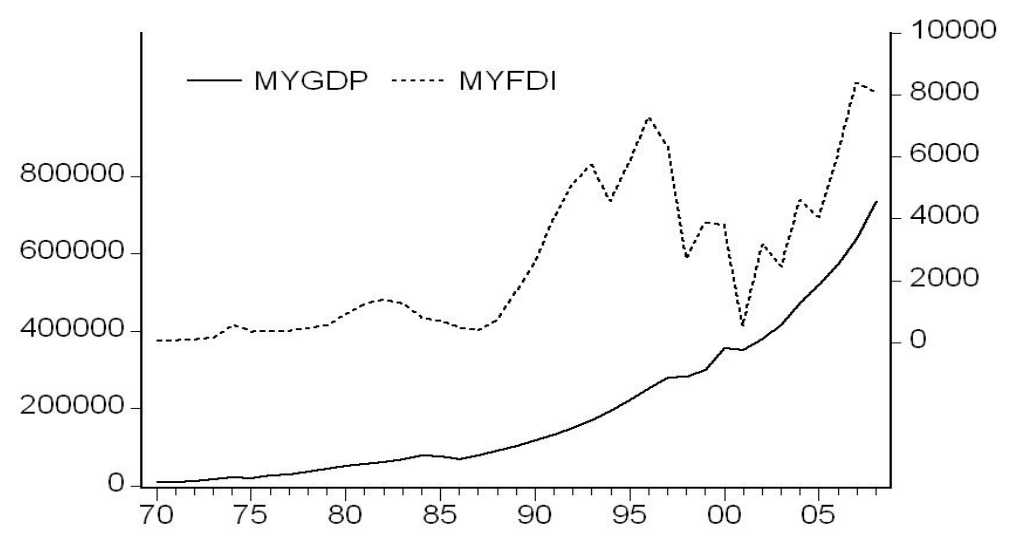

Figure 1. Comparison of absolute values of Inward FDI and GDP of Malaysia

Figure 1 shows the evolutions of the absolute values of inward FDI and GDP of Malaysia during the last three decades. According to it, there seems no clear similar moving trend between the two. Over this period, Malaysia had a consistent record of economic growth in GDP. But inward FDI experienced big ups and downs, maybe due to its open economy, on which externalities have had a major impact from time to time including the oil crises of the 1970s, the downturn in the electronics industry in the mid 1980s, and especially the Asian financial crisis in 1997. And the impact of this crisis was still being felt in the early twenty-first century. 


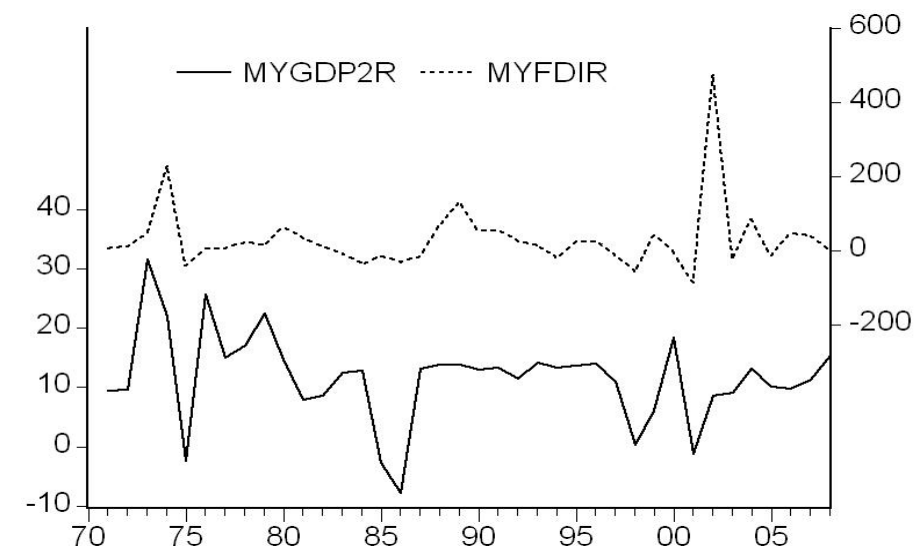

Figure 2. Comparison of relative values of Inward FDI and GDP of Malaysia

Figure 2 clearly shows that the two curves moved at a similar pace. For example, in 1975 and 2001, both reached trough. Then under the encouragement of policies, they both rebounded until the peak. Policy reforms, including the introduction of the Investment Incentives Act 1968, the establishment of free trade zones in the early 1970s, and the provision of export incentives alongside the acceleration of open policy in the 1980s, led to a surge of FDI in the late 1980s. To attract a larger inflow of FDI, the government introduced more liberal incentives including allowing a larger percentage of foreign equity ownership in enterprise under the Promotion of Investment Act (PIA), 1986. This effort resulted in a large inflow of FDI after 1987, with the inflow of FDI growing at an annual average rate of 38.7 percent between 1986 and 1996.

Response to One S.D. Innovations \pm 2 S.E.
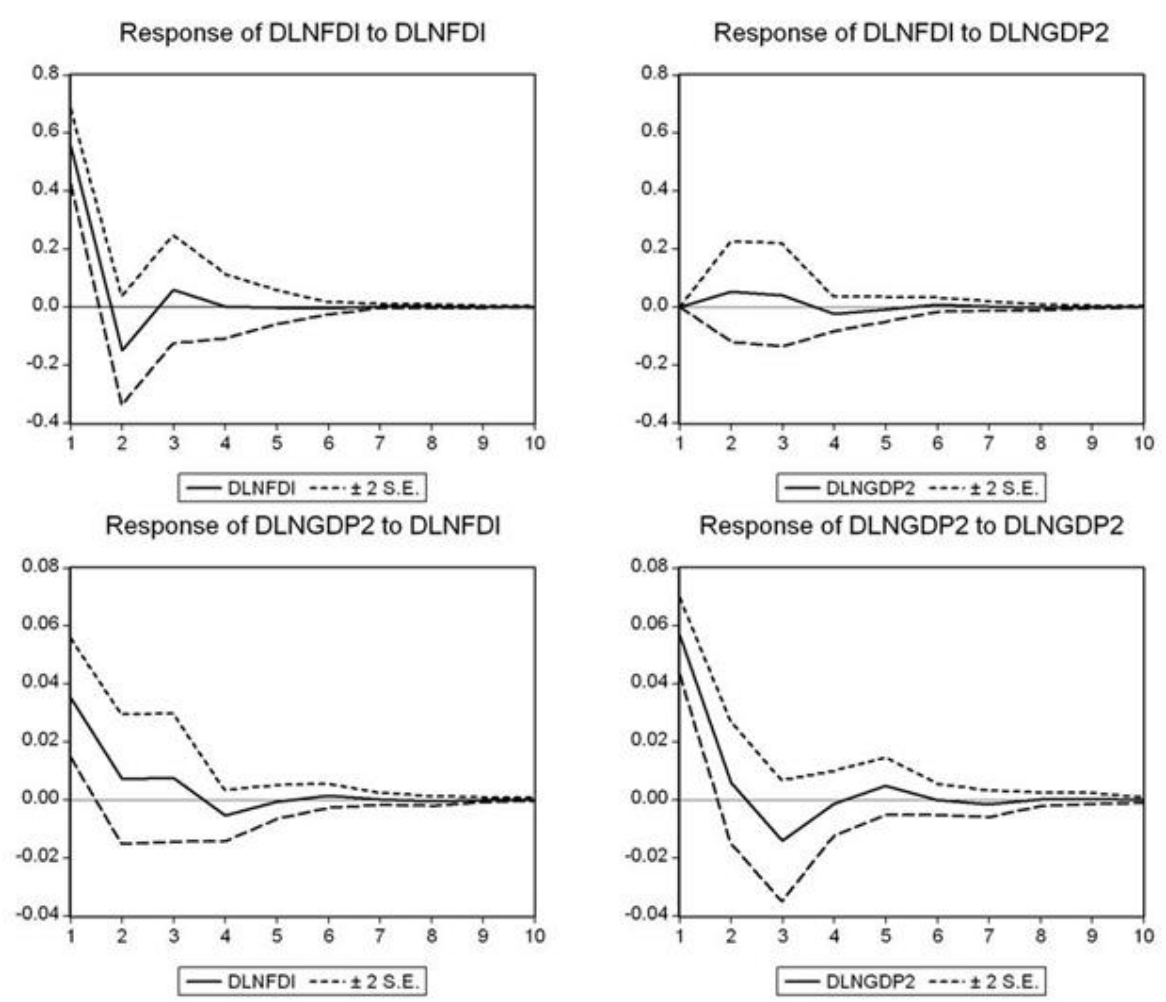

Figure 3. VAR Impulse Responses Results from Eviews 3.1

Figure 3 shows that: 1) the growth rate of Malaysia GDP responds significantly and rapidly to the variance of inward FDI, for it starts responding from the first period until the forth one and after the forth period its response comes to be stable. But when the growth rate of Malaysia GDP responses to its own variance, it takes five periods to come to be stable. 2) the inward FDI in China responds more significantly and continuously to its own variance than to the variance of GDP, as its responding to its own variance starts from the first period while to the variance of GDP starts from the second one, which means inward FDI is more sensitive towards its own movements. 